\title{
Why is it difficult to publish in high-impact journals?
}

\author{
Maria Lúcia Zanetti
}

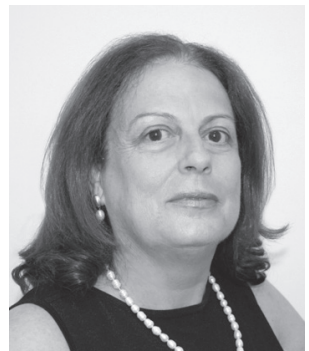

We invite Nursing researchers to reflect on Professor Bruce Alberts' assertion, from the University of California at San Francisco, USA(1), about the need to move beyond already too explored research areas, in search of others that can result in innovative studies. In other words, before making the decision to do a study, strategies need to be developed to make the decision on what scientific problem needs to be solved and establish partnerships with other qualified researchers in order to interact and seek new research methods and approaches.

The need to elaborate qualified projects, in view of competition for resources from funding agencies and requirements to publish in high-impact journals, is a theme present among Nursing researchers.

In that sense, educational institutions have stimulated researchers to establish partnerships at international centers of excellence, with financial support from research funding agencies; motivated new doctoral graduates who demonstrate potential to become promising researchers to complete their education abroad; strongly supported scientific initiation programs for Nursing undergraduates and funded research development like visiting professorships, professional advice for research design purposes and manuscript reviews and translations ${ }^{(2)}$.

This support responds to the need to structure and organize research programs with a view to the production of innovative and excellent Nursing knowledge. It should be highlighted that this movement is recent in Brazil and that the fruits of these initiatives will be picked in the medium term, in view of the time needed to prepare a researcher.

In contrast, research funding agencies and graduate programs have taken into account the dissemination of Nursing knowledge in high-impact journals in their evaluation processes. This implies that, besides scientific rigor, studies should address themes of interest in Brazil and abroad, present scientific evidence that helps nurses to make the best decisions in their clinical practice and in the elaboration of health policies, with potential to improve the population's health(3).

Brazilian researchers' efforts to submit their manuscripts to Brazilian and international high-impact journals should be highlighted. The manuscript rejection rate has been high though, and the detected problems are related to the relevance of the theme, as well as translation problems and the structure and writing of the manuscript ${ }^{(4)}$.

Therefore, besides support to produce knowledge, innovative research problems need to be sought that contribute to the development of public health policies and the qualification of nursing care. The area's substantial production covers the problem description phase but, nevertheless, there is an urgent need to seek proposals to intervene in the detected problems, as well as novel approaches and methods to study new and existing problems. This will further enhance possibilities to publish in high-impact journals. 


\section{References}

1. Fundação de Amparo à Pesquisa do estado de São Paulo. Agência FAPESP. Universidades e institutos de pesquisa devem criar ambiente propício para estudos inovadores. [acesso 9 ago 2012]; 2012. Disponível em: http://agencia. fapesp.br/16006

2. Fundação de Amparo à Pesquisa do estado de São Paulo. Agência FAPESP. Instituições de pesquisa devem investir fortemente em jovens pesquisadores. [acesso 7 ago 2012]; 2012. Disponível em: http://agencia.fapesp.br/15995

3. Wilson LL Preparing nurses for global health care. Rev. Latino-Am. Enfermagem. [periódico na Internet]. 2011; [acesso 9 ago 2012]; 19(6):1278-9. Disponível em: http://www.scielo.br/pdf/rlae/v19n6/01.pdf

4. Fundação de Amparo à Pesquisa do estado de São Paulo. Agência FAPESP. Cientistas precisam saber escrever, afirma editor. [acesso 4 julho 2012]; 2012. Disponível em: http://agencia.fapesp.br/15832

Maria Lúcia Zanetti is Associate Editor of the Latin American Journal of Nursing, and Associate Professor of the Escola de Enfermagem de Ribeirão Preto, Universidade de São Paulo, WHO Collaborating Centre for Nursing Research Development, Brazil, e-mail: zanetti@eerp.usp.br. 